\title{
Researching Politeness: From the 'Classical' Approach to Discourse Analysis ... and Back
}

\author{
Fabienne H. Baider ${ }^{1}$ - Georgeta Cislaru ${ }^{2}$. Chantal Claudel ${ }^{3}$
}

Published online: 9 June 2020

(C) Springer Nature Switzerland AG 2020

$\mathrm{Im} /$ politeness has been subject to societal recommendations for centuries, and to academic studies for decades (Leech 1977; Lakoff 1973; Brown and Levinson 1978), maybe because politeness has been identified "as a key motivation for leaving things unsaid" (Norrick and Illie 2018: 7). Politeness may be roughly defined as a frame of coded communicative norms embodying social conventionality, and impoliteness as a transgressional behaviour. This now well-established field of research provides researchers with a number of tools that have circulated widely in linguistics and beyond (intercultural studies, language teaching and language acquisition, etc.).

Different approaches to the topic have been identified along traditional divides in the field of pragmatics between on the one hand 'Anglo-American and European pragmatics' and on the other hand 'micro and macro approaches' (see Haugh and Culpeper 2018: 213). Im/politeness may be seen as a kind of test-laboratory for numerous pragmatic concepts. The concepts of face (Goffman 1959), Grice's principle of cooperation (1975), Brown and Levinson's theory (1978), or Leech's principle of politeness and maxims $(1983)^{1}$ are massively exploited for studying im/ politeness. Therefore, several definitions and frameworks of im/politeness analysis compete in the field. An early conceptualization of politeness can be found in Leech's notion of politeness as conflict avoidance, or Brown and Levinson's (1978) formulation of politeness as avoiding or reducing face-threat, while more recent conceptualizations include politeness defined as the 'interactional management of face needs' (Grainger 2011) or im/politeness seen as social practice (Haugh 2015). $\mathrm{Im} /$ politeness can also be defined as a linguistic and/or paralinguistic/extralinguistic competence-non-verbal modalities such as prosody, kinesics, gesture and facial expressions (cf. Brown and Winter 2018: 32-33), accompanying verbal rituals-to

\footnotetext{
1 'A constraint observed in human communicative behaviour, influencing us to avoid communicative discord or offence, and maintain communicative concord' (Leech 1983: 7).
}

Fabienne H. Baider

fabienne@ucy.ac.cy

1 University of Cyprus, Nicosia, Cyprus

2 Université Sorbonne nouvelle, Paris, France

3 Université Paris Nanterre, Paris, France 
manage interpersonal relations. People develop and/or learn to master various strategies allowing them to structure/shape communication and relationships (Watts 2003; Locher and Watts 2005; Spencer-Oatey 2005). Some of these strategies are part of culturally shared norms, some are shaped by more local norms/cultures, within specific communities, in relationship with language genres and registers.

\section{Im/politeness: Linguistics and the Social Turn}

Across various theoretical frameworks and alongside developments in pragmatics, the concept of im/politeness and the related methodologies have continuously evolved. Culpeper (2011) and Grainger (2011) identified three "waves" in im/politeness research (see also Culpeper and Hardaker 2017 for a review). The first wave is anchored within early pragmatic theories and linguistic pragmatics, focusing on the micro-level of interactions, i.e. the utterances; thus, it works with speech act theory and conversational implicature. Lakoff's approach $(1973,1977)$ is an example of the first wave, which favours a quantitative dimension in the research. Taking into consideration the social motivations for language use, the second wave integrates the sociocultural dimensions of im/politeness strategies, making use for instance of Bourdieu's (1977, 1991) concepts of 'symbolic capital' and especially of the 'habitus' defined as "the dispositions [which] generate practices, perceptions and attitudes which are 'regular' without being consciously co-ordinated or governed by any "rule"' (1991: 12). Fónagy's (1982) concept of énoncé lié, defined as a stancesituation module, illustrates this new turn and anticipates contextual views.

Within this second wave, a more discursive approach has emerged since the 2000s, emphasizing these broader societal dimensions and challenging the use of concepts such as "appropriate" behaviour (Mills 2011), warning against general conclusions about situated behaviours and focusing on the hearer's interpretation of the speech acts (as within Relevance theory, Watts 2003) since the meaning of speech acts is co-constructed between the participants. In that respect, Jary (1998: 13) observed that "the relevance of polite behaviour to observers should not be taken to entail its relevance to participants".

This social turn entailed the use of analytical frameworks that have been interpreted as 'post-modern thinking' (see Mills 2011, who challenges this label). Such a shift in research on impoliteness led to the development of new theoretical frameworks (Eelen 2001; Kádár and Haugh 2013: 5; Mills 2011), handling contextually situated polite and impolite strategies in order to counteract conversational moves (Culpeper 1996, 2016). These new developments are also at the origin of the merging of the two terms into a single one, that of 'im/politeness'. Interestingly, while one of the earliest studies devoted to the field focused on the topic of impoliteness within the classical model of analysis (Lachenicht 1980), it was politeness that attracted much more interest for quite a while (Culpeper and Hardaker 2017: 206). It was only in 2008 (Bousfield 2008) that impoliteness was analyzed as "strategic, systematic, sophisticated and not uncommon" (ibid) and not as "some kind of politeness failure" (ibid). Impoliteness studies are then grounded both in the classical and the discursive approaches (Locher and Bousfield 2008). 
These second-wave approaches have opened up towards corpus pragmatics since 2010 (see Romero-Trillo 2013; Rühlemann and Aijmer 2015), with the evaluation of appropriateness (cf. Fetzer 2007) entailing data/corpus observation and contextualization. Based on corpus linguistics methodologies, corpus studies of im/politeness strategies rely on more massive data, discuss the relationship between form and function, assess the pragmatic value in context and foster a renewal of pragmatic categories and data preferences (see, for an example, the study of criticism in academic book reviews by Diani 2015).

\section{Im/politeness in Situated Interactions}

In line with these developments, and still narrowing the focus, interaction pragmatics borrows approaches and tools from various fields of research such as discourse analysis, conversational analysis (Sacks et al. 1974), interactional sociolinguistics (Gumperz and Hymes 1972), or micro sociology (Goffman 1959, 1967, 1981) to put them to the test of authentic data. The objective is to identify the rules for organizing exchanges (Béal and Traverso 2010; Kerbrat-Orecchioni 1987, 2001: 59). In that regard, two levels of politeness have been acknowledged in im/politeness research (Watts et al. 1992; Eelen 2001), echoing the divorce between theory and praxis. On the one hand, the socalled Politeness 1 (or first-order Politeness) refers to everyday folk-notions or perceptions of what polite behaviour is: it is defined as behaviours "deemed to be socially and culturally appropriate in any given social activity" (Watts et al. 1992: 48). On the other hand, the so-called Politeness 2 (or second-order politeness) refers to conceptualizations formulated by researchers, and labelled by Watts (2005: xx) as a 'theoretical construct' uncoupled from 'praxis and being'.

Putting the hearer, as well as the speaker, in the foreground, and considering them as full members of the exchanges places him or her in the position of assessors of im/ polite behaviour. Thus, "(im)politeness becomes not only a matter of speakers producing behaviour but also of hearers evaluating that behaviour" (Eelen 2001: 110). In the field of linguistic pragmatics (Kerbrat-Orecchioni 1984), the study of the illocutionary value of speech acts (ordering, advising, encouraging, etc.) is associated with revealing the impact of the parameters of the situation in which they are performed (conditions of production, the relational status of the instances involved, etc.). It can also be extended to the examination of the form in which they are carried out, since an act can be performed directly or indirectly, "under the cover of another language act" (KerbratOrecchioni 2001: 52). At a more specific level of analysis, research questions on the functioning of speech acts may concern, in particular, the place given in statements to indirection (Blum-Kulka 1987), to supportive moves and/or to the internal modifiers they are composed of (Blum-Kulka et al. 1989: 281-289). 


\section{Im/politeness: Conceptual Stakes}

Since analytical approaches do not aim at identifying linguistic patterns but at recording the deployment of speech acts in context, second wave approaches have been criticized for their lack of generalization (Terkourafi 2005: 102). The so-called third wave strives to find a compromise between formal and discursive approaches. Leech (2014) advocates integrating "pragmalinguistic aspects of (im)politeness alongside sociopragmatic dimensions" (Haugh and Culpeper 2018: 216). Indeed relational approaches (e.g. Spencer-Oatey 2001, 2005), the frame-based approach to $\mathrm{im}$ /politeness (Terkourafi 2001, 2005), and the interactional approach (e.g. Arundale 2010; Haugh 2007) focus on specific linguistic forms and presuppose stable meanings while taking into account the context and including both speaker and hearer perspectives.

Thus im/politeness involves numerous issues and interfaces, depending on the viewpoint adopted. Ideology, power, face and identity are involved as expected dimensions of the hierarchical and tensional organization of society. Conventionality, norms, rituals and morality are involved as aspects of a regulated and tending-tohomogeneity social organization, but also as tools for the hierarchical organization of society (Baider and Constantinou 2014). Variation and exploitation of specific contexts (workplace, legal and healthcare settings, gender, digital communication, etc.) are involved as aspects of the epoch, genre and register sensitivity (Claudel 2015). Emotion, prosody and socialization are considered dimensions of the implication of im/politeness in sociality, relationality and identity construction (see Culpeper et al. 2017).

Normativity appears to be the driving force underpinning im/politeness (see also Haugh and Chang 2019). The impact of normativity on im/politeness is addressed through such issues as conventionality (Terkourafi 2008), morality (Kádár 2017), or implicit versus explicit knowledge. Kádár (2017) pointed out that politeness is often "mechanical", and thus we can consider that it is neutral, not directly intentional. This is due to long-acquired moral norms and may explain the variability in perception and prescription. Obviously enough, it also explains the salience of impoliteness - Kádár (2017) calls it salience by default - as a transgression of what is expected and appropriate. Impoliteness may also function as a norm-controller, inasmuch as "some relationally destructive ritual actions are necessary to establish or restore the moral order and the normative flow of an interactional event, but on the evaluative level, they might not be clearly impolite" (Kádár 2017: 9). Between politeness and impoliteness, Kerbrat-Orecchioni (1992) proposes three other categories: hyper-politeness, non-politeness and "rudeness politeness" (polirudesse). Hyperpoliteness is characterized by the massive presence of politeness markers, non-politeness (or apoliteness) by the "normal absence of any politeness marker" such as, for example, when an order is given during military training (Kerbrat-Orecchioni 2014: 300-301), and rudeness politeness through the use of im/polite behaviour not devoid of brutality (a scornful smile) whose function is "to reinforce the act of speech rather than to dampen it, and to increase its impact rather than to attenuate it" (1992: 224). 
To sum up, im/politeness issues engage assessing the appropriateness of the strategies deployed in communicative situations. Expectations are fixed in conjunction with deep-rooted moral norms - taken in a broad, context-sensitive perspectiveand with the "common ground" (Stalnaker 2002) negotiated between language speakers. This viewpoint naturally leads to cross-cultural and intercultural studies, either corpus-based or experimental.

\section{Cross-Cultural and Intercultural Im/politeness}

The concept of common ground is central to Intercultural Pragmatics, but less so to Cross-cultural pragmatics which is concerned with the functioning of speech acts from a contrastive perspective (cf. Blum-Kulka and Olshtain 1984; Blum-Kulka et al. 1989; Herbert 1989; Sifianou 1992; Katsiki and Zamouri 2002). The same act, generally identified as similar in the two or three languages and cultures compared, is observed in the light of the parameters of the situation in which it is formulated (Watts 2005; Ogiermann 2009; Bargiela-Chiappini and Kádár 2010; Ruiz de Zarobe and Ruiz de Zarobe 2012). In that respect, Diani's study of mitigation devices in English and Italian book reviews (2015) found that the use of verbs and downtoning adverbs were the commonest hedges. Such studies could be of interest for translators or language learners.

The aim of the contrastive approach is to uncover meeting points and differences between the communities under study and, in so doing, to identify universal rules (cf. Béal 2010: 32-33). It is also an opportunity to question the transcultural meaning of the speech acts under study, whose conceptual features are often considered as specific to English (Wierzbicka 1991). Contrasting research is also interested in routine formulae or, in Coulmas' own words, "sets of lexical items which are being used for the enactment of routines" (1981: 13). However, Haugh and Kádár (2017: 1) point out that most research involving several languages and politeness has adopted this cross-cultural approach in intracultural settings. Thus, many questions arise: when the corpora come from languages other than the one used to present the research, is there a loss of meaning in the translation of the corpus data or in the interpretations which are made? The issue of data translation is even more crucial when the idioms involved are far apart (cf. Claudel and Felten 2006). From a methodological point of view, these corpora raise the tricky question of their collection because of the multiple steps to be taken to obtain the necessary authorization for their recording and/or, when the supports are written (letters, e-mails, etc.), for their processing. These data also raise questions about the level of comparability of the documents or interactions concerned, the descriptive categories to be retained, and the value of the speech acts to be compared. Do these speech acts really have the same meaning in the languages being compared? While the question may seem trivial when the comparison concerns languages and cultures that are close to each other (e.g. Italian and Spanish), it is certainly not self-evident in the case of distant languages and cultures (e.g. Japanese and French or Persian and French) (Claudel 2015). This points to the need for reflection on defining the invariant of the comparison, i.e. the tertium comparationis 
or common platform of comparison (Connor and Moreno 2005; Krzeszowski 1990; Traverso 2006: 40-41).

Studies adopting an intercultural pragmatics and politeness approach focus on encounters between interactants with different cultural backgrounds such as L2 learners. When researching the linguistic behaviour of L2 speakers-which is the case when working in Interlanguage pragmatics-generalizations ignore the fact that variations inevitably occur in the way members of the same speech community define and practice im/politeness. On the other hand, in any analysis of (im)politeness the language(s) should consider the influence of the language a person speaks or where they have grown up. If there is not yet an intercultural theory of politeness (Haugh 2010; Kecskes 2013), this can be explained by the complexity of analyzing and theorizing (im)politeness from an intercultural perspective (Haugh and Kádár 2017).

Despite the complexity of the task, researching the pragmatic competence of L2 speakers, and in particular, the learning and teaching of polite behaviour, is a very well established field. However, in the earliest studies in Interlanguage pragmatics, social categories were generally reduced to the nationality or the ethnicity of the participants and considered as stable. The methodologies focus on testing the use of speech acts such as requests, complaints, compliments, refusals, etc. (e.g., BardoviHarlig and Salsbury 2004; Félix-Brasdefer and Cohen 2012; Rose 2005). The study of such speech acts can be anchored in classic first-wave politeness theory, focusing on linguistic forms such as those we find in discourse completion tasks. Corpora can then be exploited within quantitative approaches. Researchers may adopt a more discursive and relational approach, i.e. investigating im/politeness as a co-constructed speech event, uncovering the forms of appropriation of the language practices of learners through the study of differences in pragmalinguistic and sociolinguistic behaviours between native and non-native speakers (cf. Thomas 1983; Kasper and Blum-Kulka 1993; Kasper and Rose 2002).

\section{Methodological Issues: Discourse Analysis, Experimental and Historical Pragmatics}

The approaches used to capture the forms of realization of im/politeness, whether from a monolingual perspective or a comparative perspective, are closely dependent on the units of analysis selected, which can encompass larger or smaller discourse segments. Researchers in contrastive pragmatics can orient their work towards discourse analysis or contrastive pragmatics as such (Péry-Woodley 1993: 43). While the first trend stems from work in the ethnology of communication and the analysis of spoken discourse, the second is found in studies of speech acts along the lines of Searle (1975). These approaches are similar in that they both address the notion of speech act but from different angles. Whereas in contrastive pragmatics the speech act is the input that will describe how the act is performed in discourse situations, from the perspective of discourse analysts, the starting point is discourse, which is conceived as being the basis for the performance of language acts. The latter perspective is now at the heart of approaches claiming to be the 'second wave' of 
politeness research which, without necessarily adopting a comparative perspective, advocates situating itself on the level of discourse (cf. Kádár 2017: xiii).

In this context, capturing phenomena of social reality, and more specifically of $\mathrm{im} /$ politeness, through the study of the functioning of language leads to methodological choices which, in relation to the theoretical background favoured, select linguistic and pragmatic categories of analysis. In contrast to these orientations, discourse can be put under scrutiny. In this case, the functioning of linguistic markers (deixis, enunciation markers, lexical entries, etc.) becomes crucial inasmuch as they frame the speech acts to be analyzed.

The fact that politeness often passes unnoticed (Culpeper 2011) and that transgressions like impoliteness are more tangible explains the success of these transgressions in recent years. It also challenges approaches to politeness and their methodological choices. The perception of im/politeness and its underpinnings, such as moral norms (Kádár 2017) or cultural conceptualizations (Sharifian 2011) became a major concern for pragmatic studies. The development of experimental pragmatics (Sperber and Noveck 2004) enhanced methodological opportunities to measure, from the speaker's point of view, the perception, assessment and affiliation to moral and cultural baselines for various populations. The variability in individual perceptions has also become an issue for the pragmatics of im/politeness, and compels the theoretical conceptualization of linguistic strategies and their historical, social and cultural underpinnings (see also Haugh and Chang 2019). Evaluation involves forms of agency exercised in two ways, according to Haugh and Chang (2019): “(1) making different contextual assumptions about the event in question, and (2) drawing on different rationales to ground their respective classifications." Methods such as questionnaires or discourse completion tasks (DCT), derived from experimental psychology, raise the questions of:

- The non-homogeneity related to variability in the interpretation of the question formulated;

- The difference between perception and expectations, between perception and what we may call "cultural recommendations";

- The status of implicit or explicit knowledge exploited for various im/politeness strategies-for instance, some speech acts are spontaneous and unconscious, while others like apologies or requests are most of the time prepared in advance (on this last point see Labben 2016: 74).

Many studies have underlined the difficulties encountered by research in linguistic pragmatics, and this has led to the development of new methodologies, especially in the last 20 years: experimental pragmatics, corpus or discourse pragmatics, etc. Corpus linguistics can be used, for example, to research address terms or hedges, as illustrated by Diani's study of mitigation devices within a contrastive perspective. Combining methodologies might be an exciting choice for the study of (im)politeness. However, pragmatic annotation as far as politeness is concerned (DanescuNiculescu-Mizil et al. 2013) is a complex task, since most pragmatic phenomena display a form-function 'mismatch' (Rühlemann and Aijmer 2015: 11). This is the reason why automatic tagging does not give good results, and most often researchers 
resort to labour-intensive manual tagging (Rühlemann and Aijmer 2015: 11), as is the case in most of the articles in the present volume. Semi-automatic tagging is a compromise which may bring about results, as Weisser's (2015) Speech act annotation system DART suggests. However, most corpus pragmatics research adopts a hybrid approach, integrating qualitative and quantitative methodologies.

As for work on authentic or situated data, it is often the result of research into "discourse in institutional settings" when it involves non-native speakers because of the regularity and predictability of the interactional formats involved, which are largely dictated by the context of the encounter (Kasper 1999: 73). The study of verbal exchanges between native speakers covers many other contexts, whether in the same community or in several cultural communities. Research on colloquial conversation (Traverso 1996) or interactions in commercial settings (Traverso 2006; Kerbrat-Orecchioni and Traverso 2008) are some examples.

Last but not least, as shown by Culpeper and Demmen (2011) with the rise of the individual self in nineteenth century Britain, historical evolutions change pragmatic baselines, and help in explaining contemporary im/politeness strategies The upturn of historical pragmatics in the last 10-15 years is indisputable and sustains already established or newly formulated issues (Bax and Kádár 2012). The place and the impact of norms and other cultural frames and availability may thus be challenged and recontextualized (Jucker 2012). The lack of experimental data in historical pragmatics on the perception and assessment of im/politeness strategies leads to a very fertile "discourse analysis" methodology, articulating the reconstruction of social context and a fine-grained study of linguistic strategies.

\section{This Special Issue}

This special issue focuses on the im/politeness and intercultural communication interface and explores several crucial areas such as Historical pragmatics, Forensic discourse, Impoliteness, etc. The authors' choices of analytical frameworks range from a Frame-based Approach to Experimental Pragmatics, to mention but two. The shared aim is to understand the functioning or value of certain pragmatic or linguistic units in different interactional and situational contexts, taking into account the forms of circulation of discourse and/or phenomena related to what is at stake in the exchanges. Whether from a comparative angle or from monolingual perspectives, the contributors deal with the way im/politeness manifests itself in diachronic and/or synchronic contexts.

Maria Paola Tenchini and Aldo Frigerio's paper takes a theoretical turn to deal with the value of insult and pejorative terms in reported discourse. The authors draw on the class of words and expressions called pejoratives, which are characterized by their negative connotative component, in order to question the responsibility of the one who reports an offensive term, and consequently the maintenance or semantic loss of these terms in the reported context. Tenchini and Frigerio's study revisits the theoretical explanations which argue that the pejorative component has to be interpreted as impolite. They investigate in particular whether reporting a slur is labelled 
as an offensive strategy. The approach is sociolinguistic and makes use of questionnaires to test the speakers' intuition; the results show contradictions with what some theories would have predicted as far as the offensiveness of the slurs in reported speech is concerned.

Katalin Nagy's paper is situated in the field of historical pragmatics, one of the most recent branches of pragmatics. This field can shed light on phenomena of present-day languages and in particular, can challenge conclusions based on contemporary data. Nagy's work examines the evolution of the formula (no) plàcia/plagués a Déu 'may it (not) please God' in a corpus of medieval Catalan texts belonging to different genres that circulated from the thirteenth to the sixteenth century. The author explores the imperative and subjunctive moods used to give polite (or indirect) directives. The author contextualizes the study by recalling that in medieval times, the vision of the world was dominated by the place accorded to divine powers. This conception explains why, in constructions with the verb 'plaure', the position of the beneficiary is attributed to God as it was derived from formulas associated with his will. Identified as belonging to two distinct speech acts-the directive and the expressive - the construction with 'plaure' is posed as being either a wish coupled with a request to carry out the desired act or a simple wish. However, the question arises as to how to interpret the act performed in the statements analyzed. To evaluate their illocutionary force, the author notes the importance that should be given to subjectivity and uses grammatical markers (pronouns; verbal mode and tenses) as well as external, encyclopedic knowledge relating to the belief that in the Middle Ages everyone granted God power over their acts. Based on Brown and Levinson's theory (1978), the author demonstrates that the speaker urges the addressee to have the willingness to do X. This finding challenges Searle's (1975: 72) statement that the speaker can only ask the hearer whether $\mathrm{H}$ wants or wishes to do $\mathrm{X}$ but not order $\mathrm{H}$ to want or wish to do so.

From a methodological viewpoint, the contrastive approach combining form-tofunction and function-to-form perspectives, and comparing uses of speech act verbs in dialogues vs descriptive parts of the texts open avenues for renewed perspectives in pragmatic analysis.

In her article, Marianna Varga focuses on politeness strategies in a monolingual context, working on the concept of impression management in courtroom discourses. She puts under scrutiny two components of impression management (impression motivation and impression construction) used by judges, defendants and witnesses in ten Hungarian criminal and civil trials, recorded with a dictaphone and completed by written notes from direct observation and strategies of all the participants (judges, defendants, and witnesses). Five types of impression management are investigated in detail: tactical self-descriptions, attitude expressions, attributional statements, social associations, and conformity-compliance. The aim is to report on the "types of language impression management strategies" mobilized according to the profile of the protagonists, based on the assumption that accused persons will produce more of them than witnesses because of the need to reduce their sentences. It is thus shown that, if compared to what witnesses produce, the accused develop more strategies for managing the linguistic impression, particularly through politeness and respect, it is because the stakes are higher for them, so making a good impression can help to 
reduce their sentence. As for judges, it is above all the preservation of faces that they ensure by using various verbal behaviours (politeness; inclusive 'we'...), in order to encourage cooperation with witnesses. One of the main strengths of the paper is the complex and very complete approach to the parameters influencing im/politeness and determining its social functioning; indeed, the analysis takes into consideration the characteristics of the Hungarian culture, language, and legal system and demonstrates the crucial importance of the politeness strategies mobilized for a successful courtroom interrogation.

Elena Nuzzo and Diego Cortés Velásquez compare the pragmalinguistic strategies of Italian and Colombian speakers during last-minute cancellations. The aim is to understand, from the point of view of politeness, the meeting points and differences at work in the communities under study, on the hypothesis that in languages and cultures dominated by positive politeness, as is the case in Colombia, it is not as essential to soften the act of last-minute cancellation as it is in communities where negative politeness is exercised. From a methodological point of view, the examination of the responses to the questionnaires submitted to the informants led the authors to adjust what were considered as sub-acts of justification, appeal to empathy, gratitude, etc. alongside internal modifiers (Evaluation, Intensifiers and Terms of Endearment). The statistical analysis they undertook enabled them to reveal the predominance of three sub-acts common to the Italian and Colombian corpus: annulment, explanation and remedial move. Other sub-acts report significant differences between Italians and Colombians, the former preferring the call to empathy, while the latter prefer gratitude. At a more precise level of analysis, the study shows that, although shared by both communities, the explanation takes more vague forms among Colombians than among Italians, the latter tending to clarify the reasons for their last-minute cancellation.

Moreover, the Italian data quantitatively contain more internal modifiers than the Colombian sub-corpus. After analyzing sub-acts by the situation (dinner, party and drink) and the effect of social distance (low, intermediate, high) on the distribution of internal modifiers, the authors conclude that there are standard practices between groups in the choice of sub-acts. However, these are mobilized differently and lead to distinct pragmalinguistic behaviours. The desire to maintain negative face leads Italians to prefer certain acts (apology or expression of regret) and to resort to detailed explanations to justify their last-minute cancellation. At the same time, their Colombian counterparts attach more importance to positive face through, in particular, the use of the act of gratitude. The choice of modifiers also shows differences between the practices. The use of intensifiers (tanto; terribilmente) or modalisers (purtroppo) on the Italian side stresses the desire for reparation, whereas on the Colombian side, this approach is rarer.

Evgenia Vassilaki and Stathis Selimis's article combines corpus linguistics and qualitative analysis to study pragmatic competence in an intercultural context. They focus on the use of the speech act of request in daily interactions and examine the frequency and distribution of supportive moves (SMs) used by 51 children (8- and 11-year-olds) of different linguistic backgrounds learning Greek. The data were elicited via an Oral Production Task, and the focus is on the use of pre- or post-positioned modifiers to mitigate the imposition of the request. Such a sociopragmatic 
feature has been found in early stages of L2 proficiency. The quantitative and qualitative results highlight sociopragmatic awareness in a more frequent, more appropriate and more native-like fashion than reported in previous research, even though comparisons still have to be carried out with caution. The claim put forward is that one should also take into account L1 pragmatic abilities, and therefore that the development of children's general socio-cognitive abilities should also be considered in analyzing request performance studies.

The nature of the data exploited in this special issue offers different entry points and serves several purposes. Corpora can be used to collect points of view or judgements regarding certain linguistic-pragmatic behaviours. The results thus obtained through research conducted on corpora collected by DCT (Discourse Completion Test/Task), by online questionnaires or by tasks as illustrated in this volume can constitute a springboard for the development of subsequent studies based on targeted behaviours from real situations of communication.

\section{References}

Arundale, R. (2010). Constituting face in conversation: Face, facework and interactional achievement. Journal of Pragmatics, 42(8), 2078-2105.

Baider, F., \& Constantinou, M. (2014). La fureur de gagner, la rage de perdre. Étude contrastive de colère, rage et fureur en français et en grec moderne. Études romanes de Brno, 35(1), 89-104.

Bardovi-Harlig, K., \& Salsbury, T. (2004). The organization of turns in the disagreements of L2 learners: A longitudinal perspective. In D. Boxer \& A. D. Cohen (Eds.), Studying speaking to inform second language learning (pp. 199-227). Clevedon: Multilingual Matters.

Bargiela-Chiappini, F., \& Kádár, D. Z. (Eds.). (2010). Politeness across cultures. Basingstoke: Palgrave Macmillan.

Bax, M., \& Kádár, D. Z. (Eds.). (2012). Understanding historical (im)politeness: Relational linguistic practice over time and across cultures. Amsterdam: John Benjamins.

Béal, C. (2010). Les interactions quotidiennes en français et en anglais, De l'approche comparative à l'analyse des situations interculturelles. Bern: Peter Lang.

Béal, C., \& Traverso, V. (2010). 'Hello, we're outrageously punctual': Front door rituals between friends in Australia and France. Journal of French Language Studies, 20(1), 17-29.

Blum-Kulka, S. (1987). Indirectness and politeness in requests: Same or different? Journal of Pragmatics, 11, 131-146.

Blum-Kulka, S., House, J., \& Kasper, G. (Eds.). (1989). Cross-cultural pragmatics: Requests and apologies. Norwood, NJ: Ablex.

Blum-Kulka, S., \& Olshtain, E. (1984). A cross-cultural study of speech act realization patterns (CCSARP). Applied Linguistics, 5(3), 196-213.

Bourdieu, P. (1977). Outline of a theory of practice. Cambridge, NY: Cambridge University Press.

Bourdieu, P. (1991). Language and symbolic power. Cambridge: Polity Press.

Bousfield, D. (2008). Impoliteness in interaction. Amsterdam/Philadelphia: John Benjamins.

Brown, P., \& Levinson, S. C. (1978). Politeness. Some universals in language usage. In E. N. Goody (Ed.), Questions and politeness (pp. 56-310). Cambridge: Cambridge University Press.

Brown, L., \& Winter, B. (2018). Multimodal indexicality in Korean: "Doing deference" and "performing intimacy" through nonverbal behavior. Journal of Politeness Research, 15(1), 25-54.

Claudel, C. (2015). Apologies and thanks in French and Japanese personal emails: a comparison of politeness practices. Russia Journal of Linguistics, Special Issue: Intercultural Communication: Theory and Practice, 23(4), 127-145.

Claudel, C., \& Felten, G. (2006). Rendre compte d'analyses comparatives sur des corpus issus de langues/cultures éloignées. Carnets du Cediscor, 9, 23-37. 
Connor, U. M., \& Moreno, A. I. (2005). Tertium comparationis: A vital component in contrastive research methodology. In P. Bruthiaux, D. Atkinson, W. G. Eggington, W. Grabe, \& V. Ramanathan (Eds.), Directions in applied linguistics: Essays in honor of Robert B. Kaplan (pp. 153-164). Clevedon: Multilingual Matters.

Coulmas, F. (Ed.). (1981). Conversational routine. La Haye, Paris, NY: Mouton.

Culpeper, J. (1996). Towards an anatomy of impoliteness. Journal of Pragmatics, 25, 349-367.

Culpeper, J. (2011). Politeness and impoliteness. In K. Aijmer \& G. Andersen (Eds.), Sociopragmatics. Handbooks of pragmatics (Vol. 5, pp. 391-436). Berlin: Mouton de Gruyter.

Culpeper, J. (2016). Impoliteness strategies. In A. Capone \& J. Mey (Eds.), Interdisciplinary studies in pragmatics (pp. 421-445). Heidelberg, NY, Dordrecht, London: Springer.

Culpeper, J., \& Demmen, J. (2011). Nineteenth-century English politeness Negative politeness, conventional indirect requests and the rise of the individual self. Journal of Historical Pragmatics, 12(12), 49-81.

Culpeper, J., \& Hardaker, C. (2017). Impoliteness. In J. Culpeper, M. Haugh, \& D. Kádár (Eds.), The Palgrave handbook of linguistic (im)politeness (pp. 199-226). London: Palgrave.

Culpeper, J., Haugh, M., \& Kádár, D. (2017). The Palgrave handbook of linguistic (im)politeness. London: Palgrave.

Danescu-Niculescu-Mizil, C., Sudhof, M., Jurafsky, D., Leskovec, J., \& Potts, C. (2013). A computational approach to politeness with application to social factors. Proceedings of ACL 2013. https:// nlp.stanford.edu/pubs/politeness.pdf.

Diani, G. (2015). Politeness. In K. Aijmer \& C. Rühlemann (Eds.), Corpus pragmatics (pp. 169-195). Cambridge: CUP.

Eelen, G. (2001). A critique of politeness theories. Manchester: St Jerome.

Félix-Brasdefer, J. C., \& Cohen, A. D. (2012). Teaching pragmatics in the foreign language classroom: Grammar as a communicative resource. Hispania, 95(4), 650-669.

Fetzer, A. (2007). Context, contexts and appropriateness. In A. Fetzer (Ed.), Context and appropriateness (pp. 3-27). Amsterdam: John Benjamins.

Fónagy, I. (1982). Situation et signification. Amsterdam: John Benjamins.

Goffman, E. (1959). The presentation of self in everyday life. New York: Anchor Books.

Goffman, E. (1967). Interaction ritual. Essays on face-to-face behavior. Garden City, NY: Doubleday.

Goffman, E. (1981). Forms of talk. Philadelphia, PA: University of Pennsylvania Press.

Grainger, K. (2011). 'First order' and 'second order' politeness: Institutional and intercultural contexts. In Linguistic Politeness Research Group (Ed.), Discursive approaches to politeness (pp. 167-188). Berlin: Mouton de Gruyter.

Grice, H. P. (1975). Logic and conversation. In P. Cole \& J. P. Morgan (Eds.), Syntax and semantics, vol. 3. Speech Acts (pp. 41-58). London: Seminar Press.

Gumperz, J., \& Hymes, D. (1972). Directions in sociolinguistics: The ethnography of communication. New York: Holt, Rinehart \& Winston.

Haugh, M. (2007). The discursive challenge to politeness theory: An interactional alternative. Journal of Politeness Research, 3, 295-317. https://doi.org/10.1515/PR.2007.013.

Haugh, M. (2010). Intercultural (im)politeness and the micro-macro issue. In A. Trosborg (Ed.), Pragmatics across languages and cultures (pp. 139-166). Berlin/New York: De Gruyter Mouton.

Haugh, M. (2015). Im/politeness implicatures. Berlin: Mouton de Gruyter.

Haugh, M., \& Chang, W.-L. M. (2019). "The apology seemed (in)sincere": Variability in perceptions of (im)politeness. Journal of Pragmatics, 142, 207-222. https://doi.org/10.1016/j.pragma.2018.11.022.

Haugh, M., \& Culpeper, J. (2018). Integrative pragmatics and (im)politeness theory. In C. Ilie \& N. R. Norrick (Eds.), Pragmatics and its interfaces (pp. 213-239). Amsterdam: John Benjamins.

Haugh, M., \& Kádár, D. Z. (2017). Intercultural im/politeness. In J. Culpeper, M. Haugh, \& D. Z. Kádár (Eds.), The Palgrave handbook of linguistic (im)politeness (pp. 601-632). London: Parlgrave Mcmillan.

Herbert, R. K. (1989). The ethnography of English compliments and compliment responses: A contrastive sketch. In W. Oleksy (Ed.), Contrastive pragmatics (pp. 3-35). Amsterdam/Philadelphia: John Benjamins.

Jary, M. (1998). Relevance theory and the communication of politeness. Journal of Pragmatics, 30, 1-19. Jucker, A. H. (2012). Positive and negative face as descriptive categories in the history of English. In M. Bax \& D. Z. Kádár (Eds.), Understanding historical (im)politeness: Relational linguistic practice over time and across cultures (pp. 175-194). Amsterdam: John Benjamins. 
Kádár, D. (2017). Politeness, impoliteness, and ritual. Maintaining the moral order in interpersonal interaction. Cambridge: Cambridge University Press.

Kádár, D., \& Haugh, M. (2013). Understanding politeness. Cambridge: Cambridge University Press.

Kasper, G. (1999). Data collection in pragmatics research. University of Hawai' $i$ Working Papers in ESL, 18(1), 71-107.

Kasper, G., \& Blum-Kulka, S. (1993). Interlanguage pragmatics: An introduction. In G. Kasper \& S. Blum-Kulka (Eds.), Interlanguage pragmatics (pp. 3-17). Oxford, NY: Oxford University Press.

Kasper, G., \& Rose, K. R. (2002). Pragmatic development in a second language. Malden, MA: Blackwell Publishing.

Katsiki, S., \& Zamouri, S. (2002). La formulation du vœu en français, en grec et en arabe tunisien. In C. Béal, \& V. Traverso (Eds.), Marges linguistiques. https://studylibfr.com/doc/2748286/la-formulatio n-du-vœu-en-français-en-grec-et-en-arabe.

Kecskes, I. (2013). Intercultural pragmatics. Oxford: Oxford University Press.

Kerbrat-Orecchioni, C. (1984). Pour une approche pragmatique du dialogue théâtral. Pratiques: Linguistique, Littérature, Didactique, 41, 46-62.

Kerbrat-Orecchioni, C. (1987). La description des échanges en analyse conversationnelle: l'exemple du compliment. DRLAV-Documentation et Recherche en Linguistique Allemande ContemporainVincennes, 36-37, 1-53. https://doi.org/10.3406/drlav.1987.1054.

Kerbrat-Orecchioni, C. (1992). Les interactions verbales. Paris: A. Colin.

Kerbrat-Orecchioni, C. (2001). Les actes de langage dans le discours. Paris: Nathan Université.

Kerbrat-Orecchioni, C. (2014). (Im)politesse et gestion des faces dans deux types de situations communicatives: Petits commerces et débats électoraux. SOPRAG, 2, 293-326.

Kerbrat-Orecchioni, C., \& Traverso, V. (Eds.). (2008). Les interactions en site commercial, invariants et variation. Lyon: ENS Editions.

Krzeszowski, T. P. (1990). Contrasting languages: The scope of contrastive linguistics. Berlin: Mouton de Gruyter.

Labben, A. (2016). Reconsidering the development of the discourse completion test in interlanguage pragmatics. Pragmatics, 26(1), 69-91.

Lachenicht, L. G. (1980). Aggravating language: A study of abusive and insulting language. International Journal of Human Communication, 13(4), 607-688.

Lakoff, R. (1973). The logic of politeness; or, minding your p's and q's. In Papers from the ninth regional meeting of the Chicago linguistic society (pp. 292-305). Chicago: Chicago Linguistic Society.

Lakoff, R. (1977). What you can do with words: Politeness, pragmatics and performatives. In A. Rogers, B. Wall, \& J. P Murphy (Eds.), Proceedings of the Texas conference on performatives, presuppositions and implicatures (pp. 79-105). Washington, DC: Center for Applied Linguistics.

Leech, G. (1977). Language and tact. Trier: University of Trier.

Leech, G. (1983). Principles of pragmatics. Londres: Longman.

Leech, G. (2014). The pragmatics of politeness. Oxford: Oxford University Press.

Locher, M. A., \& Bousfield, D. (2008). Introduction: Impoliteness and power in language. In D. Bousfield \& M. A. Locher (Eds.), Impoliteness in language: Studies on its interplay with power in theory and practice (pp. 1-13). Berlin/New York: Mouton de Gruyter.

Locher, M., \& Watts, R. (2005). Politeness theory and relational work. Journal of Politeness Research, $1(1), 9-33$.

Mills, S. (2011). Discursive approaches to politeness and impoliteness. In Linguistic Politeness Research Group (Ed.), Discursive approaches to politeness (pp. 19-56). Berlin: De Gruyter Mouton.

Norrick, N. R., \& Ilie, C. (Eds.). (2018). Pragmatics and its interfaces. Amsterdam, Philadelphia: John Benjamins.

Ogiermann, E. (2009). On apologising in negative and positive politeness cultures. Amsterdam: John Benjamins.

Péry-Woodley, M.-P. (1993). Les écrits dans l'apprentissage, Clés pour analyser les productions d'apprenants. Paris: Hachette.

Romero-Trillo, J. (Ed.). (2013). Yearbook of corpus linguistics and pragmatics 2013: New domains and methodologies. Dordrecht: Springer.

Rose, K. (2005). On the effects of instruction in second language pragmatics. System, 33, 385-399.

Rühlemann, C., \& Aijmer, K. (2015). Corpus pragmatics: Laying the foundations. In K. Aijmer \& C. Rühlemann (Eds.), Corpus pragmatics (pp. 1-27). Cambridge: CUP.

Ruiz de Zarobe, L., \& Ruiz de Zarobe, Y. (Eds.). (2012). Speech acts and politeness across languages and cultures. Bern: Peter Lang. 
Sacks, H., Schegloff, E. A., \& Jefferson, G. (1974). A simplest systematics for the organization of turntaking for conversation. Language, 50, 696-735.

Searle, J. R. (1975). Indirect speech acts. In P. Cole \& J. Morgan (Eds.), Syntax and semantics 3: Speech acts (pp. 59-82). New York: Academic Press.

Sharifian, F. (2011). Cultural conceptualisations and language: Theoretical framework and applications. Amsterdam and Philadelphia: John Benjamins. https://doi.org/10.1075/clscc.1.

Sifianou, M. (1992). Politeness phenomena in England and Greece: A cross-cultural perspective. Oxford: Oxford University Press.

Spencer-Oatey, H. (2001). Culturally speaking: Managing rapport through talk across cultures. London/ New York: Continuum.

Spencer-Oatey, H. (2005). (Im)politeness, face and perceptions of rapport: Unpackaging their bases and relationships. Journal of Politeness Research, 1(1), 95-120.

Sperber, D., \& Noveck, I. (Eds.). (2004). Experimental pragmatics. Basingstoke: Palgrave.

Stalnaker, R. (2002). Common ground. Linguistics and Philosophy, 25, 701-721.

Terkourafi, M. (2001). Politeness in Cypriot Greek: A frame-based approach (Ph.D. dissertation). Cambridge: University of Cambridge.

Terkourafi, M. (2005). Beyond the micro-level in politeness research. Journal of Politeness Research, $1(2), 237-262$.

Terkourafi, M. (2008). Toward a unified theory of politeness, impoliteness, and rudeness. In D. Bousfield \& M. Locher (Eds.), Impoliteness in language. Language, power and social process (pp. 54-89). Berlin: Mouton de Gruyter.

Thomas, J. (1983). Cross-cultural pragmatic failure. Applied Linguistics, 4(2), 91-112.

Traverso, V. (1996). La conversation familière, analyse pragmatique des interactions. Lyon: Presses Universitaires de Lyon.

Traverso, V. (2006). Aspects of polite behaviour in French and Syrian service encounters: A data-based comparative study. Journal of Politeness Research, 2(1), 105-123.

Watts, R. (2003). Politeness. Cambridge: Cambridge University Press.

Watts, R. (2005). Linguistic politeness research: Quo vadis? In R. J. Watts, S. Ide, \& K. Ehlich (Eds.), Politeness in language: Studies in its history, theory and practice (pp. 11-47). Berlin: Mouton de Gruyter.

Watts, R. J., Ide, S., \& Ehlich, K. (1992). Politeness in language. Berlin/Boston: De Gruyter Mouton.

Weisser, M. (2015). Speech act annotation. In K. Aijmer \& C. Rühlemann (Eds.), Corpus pragmatics. Cambridge: CUP.

Wierzbicka, A. (1991). Cross-cultural pragmatics. The semantics of human interaction. Berlin: Mouton de Gruyter.

Publisher's Note Springer Nature remains neutral with regard to jurisdictional claims in published maps and institutional affiliations. 